\title{
EFFECT OF CLOVE OIL ON THE BIOCHEMICAL PROFILE OF OVOTESTIS AND HEPATOPANCREAS OF Achatina fulica
}

\author{
Yadnya A. Parvate, Liji Thayil* \\ School of Biotechnology and Bioinformatics, D.Y. Patil Deemed to be University, Sector 15, CBD Belapur, Navi Mumbai, 400614, India
}

Received - July 07, 2020; Revision - September 15, 2020; Accepted - October 10, 2020

Available Online - October 25, 2020

DOI: http://dx.doi.org/10.18006/2020.8(5).628.635

\section{KEYWORDS \\ Achatina fulica \\ Clove oil \\ Hepatopancreas \\ Ovotestis \\ Biochemical profile}

\begin{abstract}
The giant African snail Achatina fulica is widespread across the subtropical and tropical countries and has picked up the global pest status. Its voracious feeding capacity and protandrous reproduction makes it almost invincible once established. Measures to combat its menace have for long focussed on chemical molluscicides. However the rising environmental sensitivity in the past few decades has attracted the use of natural compounds to target this pest. The current study was aimed to evaluate the impact of clove oil on the biochemical profile of its ovotestis and hepatopancreas. The snails were randomly divided into three groups i.e., control, vehicle treated group (1\% Tween 80 ) and clove oil treated group. Snails in the clove oil treated group were subjected to subacute doses of clove oil ( $20 \%$ and $60 \%$ of $\mathrm{LD}_{50}$ value/24 hrs) by topical application. The activity levels of vital enzymes namely acetylcholinesterase, acid phosphatase, alkaline phosphatase, protease and lactic dehydrogenase were pertinently altered in the ovotestis and hepatopancreas of the clove oil treated snails as compared to the control. Contents of important biomolecules like DNA, RNA, protein, and phospholipids were reduced, the level of lipid peroxidation was significantly enhanced with a concomitant decrease in glutathione content in clove oil treated groups vis-avis control in both the tissues studied, highlighting the toxic effect of clove oil to the snail. Thus it is suggested that clove oil can be used in controlling the population of this harmful pest.
\end{abstract}

* Corresponding author

E-mail: liji@dypatil.edu ( Dr. Liji Thayil)

Peer review under responsibility of Journal of Experimental Biology and Agricultural Sciences.

Production and Hosting by Horizon Publisher India [HPI] (http://www.horizonpublisherindia.in/).

All rights reserved.
All the articles published by Journal of Experimental Biology and Agricultural Sciences are licensed under a Creative Commons Attribution-NonCommercial 4.0 International License Based on a work at www.jebas.org.

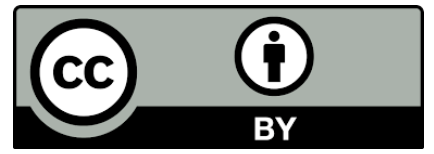




\section{Introduction}

The giant African snail Achatina fulica has been in the spotlight for the damages it has inflicted on the agri-horticultural fields globally. It is known to be amongst the world's worst hundred invasive species as stated by the International Union for Conservation of Nature and Natural resources (IUCN) and has spread out globally from its native home in East Africa (Lowe et al., 2000). In India, it has dispersed in large numbers since its introduction in Calcutta almost 140 years ago (Naggs, 1997), due to its high reproductive capacity (lays 250- 300 eggs in a year per pair) and generalist feeding pattern (feeds on more than 500 species of plants) (Raut \& Ghose, 1984; Sajeev, 2011).

A. fulica induces threefold damages to tropical agriculture. First, there is a substantial loss of agricultural productivity due to herbivory on crop plants, this damage may also be caused through the transmission of plant pathogens. Secondly, there is a huge cost of labour and materials involved in managing the pest population in such situations. Thirdly, enforced changes in agricultural practices have to be induced such as limiting the crop species to be grown in the region to those resistant to A. fulica resulting in loss of production of a conventional crop (Raut \& Barker, 2002). Unfortunately, the snail spurt continues, recently it was found invading and causing major damages in the urban areas of the Chandrapur district, Maharashtra (Chatap et al., 2020). In many Asian, Pacific, and American communities, it transmits human parasites and pathogens in slime trails or when infested snails are eaten raw or undercooked (Nelson, 2012). One such pathogen is rat lungworm-Angiostrongylus cantonensis, which causes angiostrongyliasis and Eosinophilic meningoencephalitis in humans (Vitta et al., 2011). The faeces of this snail mediates the spread of the black pod disease of plants caused by Phytopthora palmivora (Raut \& Barker, 2002). An array of literature pertaining to its management is available both at the global level and in the Indian context (Jayashankar et al., 2013). For a long time, the control measures for combating this snail heavily relied on chemical molluscicides. Some of the commonly used chemical molluscicides are metaldehyde (Basavaraju et al., 2001; Vanitha et al., 2008; Ciomperlik et al., 2013); carbamates (Shevale \& Bedse, 2009; Ciomperlik et al., 2013), and organophosphates (Saxena \& Mahendra, 2000; Justin et al., 2008). Although these chemical molluscicides are effective they cause enormous damage to the environment and non - target species (Kashyap et al., 2019). Hence these days natural compounds are preferred for snail control. Essential oils derived from plants help in controlling the snail population by their selective action, and little or no harmful effects on the non- target organisms and the environment (Isman, 1999). Also, these essential oils are biodegradable and the chances of molluscs acquiring resistance to them is very low (Kashyap et al., 2019). The toxic effect of clove oil is well elucidated on various organisms such as bacteria, human beings (Kumar et al., 2011), insects (Afonso et al., 2012), fish species viz., Danio rerio and Poecilia reticulata (Dolezelova et al., 2011), and albino rats (Shalaby et al., 2011). The negative impact of clove oil on the survival and histology of various tissues of A. fulica was comprehended by Parvate \& Thayil (2017). Previous studies have also revealed that the reproductive efficiency of A. fulica is severely compromised on treatment with clove oil (Parvate et al, 2016). Thus an attempt was made to investigate the biocidal potential of clove oil as a molluscicide on the biochemical profile of ovotestis and hepatopancreas of A. fulica as these are the major organs supporting its prodigious reproduction and voracious feeding habit.

\section{Materials and Methods}

\subsection{Test chemicals and test solution}

Clove oil and Tween 80 were purchased from Merck and Himedia respectively. $1 \%$ Tween 80 solution was utilized as a vehicle compound. The test solutions i.e., required concentrations of clove oil dissolved in $1 \%$ Tween 80 solution, were freshly prepared just before use for all the experiments performed.

\subsection{Collection and maintenance of snails}

Healthy adult snails of A. fulica were collected from local gardens of Navi Mumbai and Jijamata Udyan, Mumbai, India. These were maintained at a temperature of $25^{\circ} \mathrm{C} \pm 2{ }^{\circ} \mathrm{C}$ in transparent plastic boxes measuring (14" x 10.5 " $\left.\times 10^{\prime \prime}\right)$. A $4 \mathrm{~cm}$ layer of the garden soil was laid down at the bottom of the boxes. The open ends of these boxes were covered with muslin cloths which were tied to the boxes to prevent the animals from escaping and to facilitate the free flow of air. Snails were fed on fresh cabbage daily and appropriate humidity was maintained by sprinkling water on the soil layer at regular intervals.

\subsection{Experimental design}

The snails were randomly divided into three groups i.e. Control, vehicle-treated, and clove oil-treated group with 24 snails in each group. The snails in the control group were maintained at optimum conditions without any treatment, while the vehicletreated group was given $1 \mathrm{ml}$ of $1 \%$ Tween 80 solution, and clove treated groups were subjected to $20 \%$ and $60 \%$ value of $\left(\mathrm{LD}_{50} / 24 \mathrm{hrs}\right)$ of clove oil prepared in $1 \%$ Tween 80 solution $(\mathrm{v} / \mathrm{v})$. The technique of topical application was utilized for the administration of the test compound as well as the vehicle. The snails from each group were dissected after 24 hours of treatment and their tissues were excised, cleaned, weighed, and were stored at $-80^{\circ} \mathrm{C}$ until further analysis. The assays were performed in triplicates for each parameter $(\mathrm{N}=6)$. 


\subsection{Biochemical assays}

\subsubsection{Estimation of DNA and RNA}

DNA and RNA contents were estimated by the method of Schneider (1957). For both the parameters $50 \mathrm{mg}$ each of ovotestis and $100 \mathrm{mg}$ each of hepatopancreas were homogenized in 5\% TCA at $90^{\circ} \mathrm{C}$. The homogenates were centrifuged at 10,000 r.p.m for 10 min at $4^{\circ} \mathrm{C}$ and the resulting supernatants were used as samples for DNA and RNA estimations respectively.

\subsubsection{Estimation of Protein, Phospholipid, Lipid peroxidation (LPx) and Glutathione content (GSH)}

For the aforementioned estimations, $50 \mathrm{mg}$ each of ovotestis and $100 \mathrm{mg}$ each of hepatopancreas were homogenized in $0.01 \mathrm{M}$ Tris$\mathrm{HCl}$ buffer at $\mathrm{pH} 7.4$ for $5 \mathrm{~min}$ in an ice bath. The homogenates were centrifuged at 10,000 r.p.m for $40 \mathrm{~min}$ for protein estimation and $10 \mathrm{~min}$ each for the other estimations, at $4^{\circ} \mathrm{C}$. The resulting supernatants were used as samples for the respective estimations.

The protein concentration was detected by adopting the method of Lowry et al. (1951) while, the estimation of phospholipid was carried out by Fiske \& Subbarow (1925) method. For analyzing the level of lipid peroxidation, the method of Okhawa et al. (1979) was used and GSH content was assessed as per the method described by Moron et al. (1979).

2.4.3. Enzyme assays - Acetylcholinesterase (AChE), Acid phosphatase (ACP), Alkaline phosphatase (ALP), Protease and Lactate dehydrogenase (LDH) assays

For enzyme assays, $50 \mathrm{mg}$ each of ovotestis and $50 \mathrm{mg}$ each of hepatopancreas (100 $\mathrm{mg}$ for protease and $\mathrm{LDH})$ were homogenized in appropriate buffers $(0.1 \mathrm{M}$ phosphate buffer at $\mathrm{pH} 8.0$ for $\mathrm{AChE}$, $50 \mathrm{mM}$ citrate buffer at $\mathrm{pH} 5.3$ for ACP, $50 \mathrm{mM}$ glycine $\mathrm{NaOH}$ buffer at $\mathrm{pH} 10.4$ for ALP, $50 \mathrm{mM}$ Tris $\mathrm{HCl}$ buffer at $\mathrm{pH} 8.0$ for protease and $0.1 \mathrm{M}$ phosphate buffer at $\mathrm{pH} 8.0$ for $\mathrm{LDH}$ ) for $5 \mathrm{~min}$ in an ice bath and centrifuged at 10,000 r.p.m for $10 \mathrm{~min}$ at $4^{\circ} \mathrm{C}$. The respective supernatants were then utilized as the enzyme source for the assays.

Acetylcholinesterase activity was analyzed by adopting the method of Ellman et al. (1961) while, acid phosphatase and alkaline phosphatase activities were measured by following the method of Bergmeyer et al. (1974). Protease assay was performed according to the method of Windle \& Kelleher (1997). The method described by King (1965) was followed for the LDH assay.

\subsection{Statistical Analysis}

Data were expressed as mean \pm Standard error of the mean (S.E.M.), analyzed by one-way analysis of variance (ANOVA), and the means separated by p values: $(* \mathrm{p}<0.05),(* * \mathrm{p}<0.01),(* * * \mathrm{p}<0.001)$.

\section{Results}

In ovotestis the nucleic acids (DNA and RNA) and the protein contents of both the treated groups ( $20 \%$ and $60 \%$ of $\mathrm{LD}_{50} / 24 \mathrm{hrs}$ ) of clove oil were significantly lowered as compared to the control group. The content of phospholipids which are important constituents of the cell membrane were found reduced to an extremely significant extent in both the clove oil-treated groups. Also, the treatment with clove oil led to significant elevation in the levels of lipid peroxidation in both the groups vis-à-vis control with a concomitant reduction in the glutathione content. However, this reduction was not significantly different from the glutathione content of the control. The vehicle (1\% Tween 80$)$ treated group had values similar to the control group for most of the parameters studied. The only exceptions were the DNA content and level of lipid peroxidation where the deviation was significant as compared to the control group (Table 1).

In hepatopancreas the amount of DNA and RNA was reduced in the groups treated with both lower and higher subacute doses of clove oil. However, the reduction in DNA content was nonsignificant while in the case of RNA content, an extremely significant difference was reported from the control group. The protein and phospholipid contents revealed a significant decline in both the treated groups. Elevation in the lipid peroxidation level was extremely significant in both the clove oil treated groups with a concurrent decline in the glutathione content. However significant decline in GSH content was noticed in the group subjected to a higher subacute dose of clove oil only. The results of the vehicle control group were similar to the control group except for its RNA content which demonstrated significant reduction visà-vis control (Table 2).

In ovotestis the activity levels of the enzymes acetylcholinesterase, lysosomal marker enzyme acid phosphatase, and protease were found to be lowered on treatment with clove oil, with significant impact observed in the groups exposed to $\left(60 \%\right.$ of $\left.\mathrm{LD}_{50} / 24 \mathrm{hrs}\right)$ of clove oil. Clove oil enhanced the level of activity of the enzyme lactate dehydrogenase significantly in the group exposed to its lower subacute dose and extremely significantly in the group exposed to its higher subacute dose. The activity of the enzyme alkaline phosphatase was altered non significantly. The vehicle (1\% Tween 80) treated group exhibited activity level of all the enzymes analogous to the control group, except the activity level of lactate dehydrogenase which exhibited a significant increase as compared to the control group (Table 3). In hepatopancreas the activity level of all the five vital enzymes namely acetylcholinesterase, acid phosphatase, alkaline phosphatase, protease, and lactic dehydrogenase was altered at both exposures of clove oil (20\% and $60 \%$ of $\mathrm{LD}_{50}$ value $/ 24 \mathrm{hrs}$ ) but this was non-significant in relation to the control. The vehicle control group exhibited the activity level of all the enzymes close to the control group (Table 4). 
Table 1 Effect of clove oil on the biochemical parameters of ovotestis of A. fulica

\begin{tabular}{|c|c|c|c|c|}
\hline Parameter & Control & $\begin{array}{l}\text { Vehicle } \\
\text { Control }\end{array}$ & $\begin{array}{c}20 \% \text { of } \\
\mathrm{LD}_{50} / 24 \mathrm{hrs}\end{array}$ & $\begin{array}{c}60 \% \text { of } \\
\mathrm{LD}_{50} / 24 \mathrm{hrs}\end{array}$ \\
\hline DNA ( $\mu \mathrm{g} / \mathrm{mg}$. tissue $)$ & $1.669 \pm 0.049$ & $1.502 \pm 0.041 *$ & $1.457 \pm 0.042 * *$ & $1.325 \pm 0.041 * * *$ \\
\hline RNA ( $\mu \mathrm{g} / \mathrm{mg}$. tissue) & $1.621 \pm 0.027$ & $1.57 \pm 0.045^{\mathrm{NS}}$ & $1.443 \pm 0.020 * * *$ & $1.383 \pm 0.046^{* *}$ \\
\hline Protein mg.tissue & $0.042 \pm 0.001$ & $0.041 \pm 0.001^{\mathrm{NS}}$ & $0.040 \pm 0.001^{*}$ & $0.039 \pm 0.001 *$ \\
\hline Phospholipid $\left(10^{-3}\right)(\mu \mathrm{M} / \mathrm{mg}$. tissue) & $1.967 \pm 0.119$ & $1.865 \pm 0.134^{\mathrm{NS}}$ & $1.345 \pm 0.057^{* * *}$ & $1.27 \pm 0.080^{* * *}$ \\
\hline LPx ( $\mu \mathrm{g} / \mathrm{mg}$. tissue) & $0.102 \pm 0.001$ & $0.105 \pm 0.001 * *$ & $0.191 \pm 0.001 * * *$ & $0.130 \pm 0.001 * * *$ \\
\hline GSH ( $\mu \mathrm{g} / \mathrm{mg}$. tissue) & $0.543 \pm 0.017$ & $0.547 \pm 0.015^{\mathrm{NS}}$ & $0.523 \pm 0.006^{\mathrm{NS}}$ & $0.545 \pm 0.008^{\mathrm{NS}}$ \\
\hline
\end{tabular}

Values are expressed as Mean \pm SEM for six animals in each group (One way ANOVA); NS-Non significant $(* \mathrm{p}<0.05),(* * \mathrm{p}<0.01),\left({ }^{* * *} \mathrm{p}<0.001\right)$.

Table 2 Effect of clove oil on the biochemical parameters of hepatopancreas of A. fulica

\begin{tabular}{|ccccc|}
\hline Parameter & Control & $\begin{array}{c}\text { Vehicle } \\
\text { control }\end{array}$ & $\begin{array}{c}\text { 20\% of } \\
\text { LD }_{50} / 24 \mathrm{hrs}\end{array}$ & $\begin{array}{c}60 \% \text { of } \\
\mathrm{LD}_{50} / 24 \mathrm{hrs}\end{array}$ \\
\hline DNA $(\mu \mathrm{g} / \mathrm{mg}$. tissue $)$ & $1.322 \pm 0.14$ & $1.204 \pm 0.12^{\mathrm{NS}}$ & $1.042 \pm 0.064^{\mathrm{NS}}$ & $0.978 \pm 0.095^{\mathrm{NS}}$ \\
\hline RNA $(\mu \mathrm{g} / \mathrm{mg}$. tissue) & $5.57 \pm 0.433$ & $4.26 \pm 0.328^{*}$ & $1.81 \pm 0.158^{* * * *}$ & $1.365 \pm 0.1^{* * *}$ \\
\hline Protein mg.tissue & $0.104 \pm 0.01$ & $0.081 \pm 0.01^{\mathrm{NS}}$ & $0.070 \pm 0.003^{* *}$ & $0.067 \pm 0.002^{* *}$ \\
\hline Phospholipid $\left(10^{-3}\right)(\mu \mathrm{M} / \mathrm{mg}$. tissue $)$ & $5.15 \pm 0.289$ & $4.91 \pm 0.323^{\mathrm{NS}}$ & $3.88 \pm 0.334^{*}$ & $3.325 \pm 0.431^{* *}$ \\
\hline LPx $(\mu \mathrm{g} / \mathrm{mg}$. tissue $)$ & $0.040 \pm 0.002$ & $0.038 \pm 0.003^{\mathrm{NS}}$ & $0.080 \pm 0.005^{* * *}$ & $0.098 \pm 0.003^{* * *}$ \\
\hline GSH $(\mu \mathrm{g} / \mathrm{mg}$. tissue $)$ & $1.60 \pm 0.137$ & $1.61 \pm 0.213^{\mathrm{NS}}$ & $1.38 \pm 0.157^{\mathrm{NS}}$ & $1.07 \pm 0.161^{*}$ \\
\hline
\end{tabular}

Values are expressed as Mean \pm SEM for six animals in each group (One way ANOVA); NS-Non significant $(* \mathrm{p}<0.05),(* * \mathrm{p}<0.01),(* * * \mathrm{p}<0.001)$.

Table 3 Effect of clove oil on the activity levels of vital enzymes of ovotestis of A. fulica

\begin{tabular}{|ccccc|}
\hline Parameter & Control & $\begin{array}{c}\text { Vehicle } \\
\text { control }\end{array}$ & $\begin{array}{c}20 \% \text { of } \\
\mathrm{LD}_{50} / 24 \mathrm{hrs}\end{array}$ & $\begin{array}{c}60 \% \text { of } \\
\mathrm{LD}_{50} / 24 \mathrm{hrs}\end{array}$ \\
\hline $\begin{array}{c}\text { Acetylcholinesterase( } \mu \mathrm{M} \text { of SH } \\
\text { hyd/min/mg.protein) }\end{array}$ & $0.16 \pm 0.02$ & $0.18 \pm 0.006^{\mathrm{NS}}$ & $0.161 \pm 0.01^{\mathrm{NS}}$ & $0.099 \pm 0.01^{*}$ \\
\hline $\mathrm{ACP}(\mu \mathrm{M}$ of PNP/min/mg.protein) & $2.67 \pm 0.175$ & $2.58 \pm 0.10^{\mathrm{NS}}$ & $2.22 \pm 0.20^{\mathrm{NS}}$ & $1.83 \pm 0.171^{* *}$ \\
\hline $\mathrm{ALP}(\mu \mathrm{M}$ of PNP/min/mg.protein) & $1.54 \pm 0.09$ & $1.63 \pm 0.06^{\mathrm{NS}}$ & $1.71 \pm 0.14^{\mathrm{NS}}$ & $1.57 \pm 0.15^{\mathrm{NS}}$ \\
\hline Protease $\left(10^{-2}\right) \mu \mathrm{M}$ tyr.eq.rel/mg.protein & $0.89 \pm 0.06$ & $0.88 \pm 0.04^{\mathrm{NS}}$ & $0.79 \pm 0.06^{\mathrm{NS}}$ & $0.68 \pm 0.02^{* *}$ \\
\hline LDH $(\mathrm{I} . \mathrm{U} / \mathrm{mg}$ protein) & $30.09 \pm 3.70$ & $43.31 \pm 4.46^{*}$ & $46.89 \pm 4.44^{*}$ & $62.79 \pm 2.84^{* * *}$ \\
\hline
\end{tabular}

Values are expressed as Mean \pm SEM for six animals in each group (One way ANOVA). NS- Non significant, $(* \mathrm{p}<0.05),\left({ }^{* *} \mathrm{p}<0.01\right)$, $(* * * \mathrm{p}<0.001)$

Table 4 Effect of clove oil on the activity levels of vital enzymes of hepatopancreas of A. fulica

\begin{tabular}{|ccccc|}
\hline Parameter & Control & $\begin{array}{c}\text { Vehicle } \\
\text { control }\end{array}$ & $\begin{array}{c}\text { 20\% of } \\
\mathrm{LD}_{50} / 24 \mathrm{hrs}\end{array}$ & $\begin{array}{c}60 \% \text { of } \\
\mathrm{LD}_{50} / 24 \mathrm{hrs}\end{array}$ \\
\hline $\begin{array}{c}\text { Acetylcholinesterase }(\mu \mathrm{M} \text { of SH } \\
\text { hyd/min/mg.protein) }\end{array}$ & $4.158 \pm 0.969$ & $3.66 \pm 0.547^{\mathrm{NS}}$ & $3.55 \pm 0.539^{\mathrm{NS}}$ & $3.515 \pm 0.412^{\mathrm{NS}}$ \\
\hline ACP $(\mu \mathrm{M}$ of PNP/min/mg.protein $)$ & $1.41 \pm 0.137$ & $1.42 \pm 0.22^{\mathrm{NS}}$ & $1.43 \pm 0.11^{\mathrm{NS}}$ & $1.75 \pm 0.30^{\mathrm{NS}}$ \\
\hline ALP $(\mu \mathrm{M}$ of PNP/min/mg.protein) & $5.07 \pm 1.28$ & $5.25 \pm 1.44^{\mathrm{NS}}$ & $6.68 \pm 1.71^{\mathrm{NS}}$ & $7.145 \pm 1.27^{\mathrm{NS}}$ \\
\hline Protease $\left(10^{-2}\right) \mu \mathrm{M}$ tyr.eq.rel/mg.protein & $0.58 \pm 0.11$ & $0.58 \pm 0.12^{\mathrm{NS}}$ & $0.41 \pm 0.02^{\mathrm{NS}}$ & $0.45 \pm 0.05^{\mathrm{NS}}$ \\
\hline LDH (I.U/mg protein) & $63.10 \pm 8.97$ & $52.08 \pm 4.75^{\mathrm{NS}}$ & $50.08 \pm 10.37^{\mathrm{NS}}$ & $43.31 \pm 5.86^{\mathrm{NS}}$ \\
\hline
\end{tabular}

Values are expressed as Mean \pm SEM for six animals in each group (One way ANOVA). NS- Non significant. 


\section{Discussion}

The major active components of clove oil are eugenol (88.58\%), eugenol acetate $(5.62 \%)$, and $\beta$-caryophyllene $(1.38 \%)$ (Chaieb et al, 2007). The results of the current study revealed that clove oil exerted its toxic effects on both ovotestis and hepatopancreas on its subacute exposure mediated through its aforesaid components. The reduction in the concentrations of important biomolecules like DNA, RNA, proteins, phospholipids, an elevation in the level of lipid peroxidation with the corresponding decline in GSH content was pertinent in both ovotestis and hepatopancreas. However, the activity levels of the vital enzymes namely AChE, ACP, ALP, protease, and $\mathrm{LDH}$ were affected to a greater extent in ovotestis as compared to the hepatopancreas.

The DNA, RNA, and protein levels of both the tissues were significantly lowered on subacute treatment with clove oil in contrast to the controls. The reduced DNA content had an inhibitory effect on the transcription activity which lead to reduced synthesis of RNA. This is in concordance to the results obtained by Atwa \& Bakry (2019) who revealed the genotoxic effect of the drug mefloquine on the soft tissues of the snail Lymnaea natalensis and suggested that the drug acted as a potent inhibitor of DNA synthesis resulting in the lowering of RNA levels. Since RNA plays an important role in protein synthesis, the inhibition of RNA synthesis at the transcription level lowers the protein content (Singh \& Singh, 2010). Compromised uptake of amino acids in the polypeptide chain during protein synthesis due to the action of the chemical administered can also lower the protein content (Singh et al., 2020). These reasons well explain the diminished protein content of the clove oil treated tissues observed in the current study. Similar results in terms of decline in nucleic acids and protein contents were reported by Singh et al. (2010) on exposing the snail L. acuminata to sublethal doses of deltamethrin.

In the present study, the level of lipid peroxidation was enhanced and the glutathione content was compromised on sub-lethal exposure to clove oil. Lipid peroxidation is one of the primary causes of cellular damage and the increase in lipid peroxides results in oxidative stress (Ming et al., 2010). Malondialdehyde (MDA) serves as the biomarker of lipid peroxidation and its quantification directly reveals the level of oxidative stress (Tao et al., 2013). Thus the elevated MDA content of the treated tissues in the present study suggested that clove oil might have induced oxidative stress in the snails. Significant depletion in the phospholipid level was observed in the treated tissues of ovotestis and hepatopancreas. This is probably the manifestation of oxidative degradation of membrane phospholipids which further confirms the lipid peroxidation ability of clove oil. Results of the current study are supported by those obtained by Rao \& Singh (2000) who reported a significant decline in the phospholipid level and an elevation in the MDA levels in ovotestis of the snail $A$. fulica exposed to plant derived molluscicides.
Glutathione acts as a reducing agent and protects cells against peroxidative attack by scavenging free radicals (Verma et al., 2007, Zitka et al., 2012). Thus the reduction in GSH content in all the clove oil treated tissues could have been probably due to its utilization in scavenging of reactive oxygen species i.e. lipid peroxides generated on treatment. A drastic decrease in the GSH content with an enhanced level of lipid peroxidation was observed by Bakry et al. (2013) in the snails Biomphalaria alexandrina exposed to the pesticides diazinon and profenfos. Results of the current study are following the observations of Khalil (2015) who demonstrated that sublethal exposure of Chlorpyrifos induced oxidative stress in Lanistes carinatus which lead to elevated MDA level and depleted GSH content in its hepatopancreas and nervous tissue.

Acetylcholinesterase (AChE) enzyme is vital for normal behavior and muscular function as it regulates nervous transmission by reducing the concentration of acetylcholine (ACh) in the junction through AChE - catalyzed hydrolysis of acetylcholine to acetate and choline (Kopecka \& Pempkowiak, 2004). Earlier studies by Yadav \& Singh (2016) have revealed a reduction in AChE activity in $L$. acuminata treated with stem bark extracts of Croton tiglium and Codiaeum variegatum. However, the treatment of snails with clove oil in the present study caused significant depletion in AChE activity only in the ovotestis exposed to $60 \%$ of $\mathrm{LD}_{50} / 24 \mathrm{hrs}$.

Enzymes ACP and ALP are known to get influenced by molluscicidal treatment, they catalyze the breakdown of ester bonds in the orthophosphate esters under acidic and alkaline conditions, respectively (Daihan, 2008). In the current study, the activity levels of both ACP and ALP were altered in the treated tissues, however, the alteration was significant only in the activity of ACP in ovotestis exposed to a higher sub-acute dose of clove oil. A significant alteration in the activity of ACP and a non - significant change in the activity level of ALP was observed by Wang et al. (2018) on treating the snail B. straminea with synthetic derivatives of pyridylphenyl ureas which supports the findings of this study.

Proteases are enzymes catalyzing proteolysis which is directly or indirectly involved in most of the cellular processes (Schaller, 2004). Proteolysis is essential to supply the pool of amino acids essential for synthesizing new proteins as well as for the removal of damaged proteins when under stress (Palma et al., 2002). A reduction in protease activity was noted by Mahmoud et al. (2020) in the gut of Zebra fish (Danio rerio) treated with Fenvalerate which they associated with its altered substrate specificity. The reduction in the protease activity in the clove oil treated tissues of ovotestis and hepatopancreas in the current study may also be attributed to the same.

In the present study elevation in lactate dehydrogenase (LDH) activity was observed in the treated tissues which probably suggests a bias towards the anaerobic glycolytic pathway, as LDH is associated with cellular metabolic activity and is a pivotal 
enzyme between the glycolysis and citric acid cycle (Singh et al., 2013). Previous studies by Gohary et al. (2011) on two land snails - Monacha cantiana and Eobania vermiculata exposed to three molluscicidal baits also presented results similar to the ones obtained in the current study. All the baits used in their study resulted in increased LDH level in the treated tissues.

\section{Conclusion}

This study indicates that clove oil induced toxicity in both ovotestis and hepatopancreas of the snail A. fulica probably mediated through the oxidative stress mechanism.However, the impact was more profound on ovotestis as compared to hepatopancreas. The disturbed biochemical profile of ovotestis (the organ supporting prodigious reproduction of this snail) implies that clove oil inflicted an assault on its structural integrity leading to its malfunctioning. This substantiates the fact that the molluscicides act by either directly hindering metabolic pathways of the snails or by controlling their rate of proliferation. Based on the results of the current study it is proposed that clove oil can act as a prospective lead compound in controlling the population of this snail.

\section{Acknowledgments}

School of Biotechnology and Bioinformatics, D.Y. Patil Deemed to be University, Navi Mumbai for providing the infrastructure to carry out the research.

\section{Conflict of interest}

The authors declare that they have no conflict of interest.

\section{References}

Afonso RS, Renno MN, Glaucia BCA, Slana GBCA, Franca TCC (2012) Aspectos quimicos e biologicos do oleo essencial de cravoda-india. Revista Virtual de Quimica 4:146-161.

Atwa MT, Bakry FA (2019) Effect of mefloquine on biological and biochemical aspects of Lymnaea natalensis snails infected with Fasciola gigantica. The Journal of Basic and Applied Zoology 80: 1-9.

Bakry FA, El-homossany K, Abd El- Atti MS, Ismaiel SM (2013) Alterations in the fatty acid profile, antioxidant enzymes and protein pattern of Biomphalaria alexandarina snails exposed to the pesticides diazinon and profenofos. Global Journal of Pharmacy \& Pharmaceutical Sciences 1: 27-36.

Basavaraju BS, Kulapati Hipparagi Chinnamadegowda C, Krishnamurthy N (2001) Management of giant African snail in betelvine garden. Current Research 30: 116-118.
Bergmeyer HU, Gawehn K, Grassl M (1974) Methods of Enzymatic Analysis, Vol.1, Academic Press Inc, New York.

Chaieb K, Hajlaoui H, Zmantar T, Kahla-Nakbi AB, Rouabhia M, Mahdouani K, Bakhrouf A (2007) The chemical composition and biological activity of clove essential oil, Eugenia caryophyllata (Syzgium aromaticum L. Myrtaceae): a short review. Phytotherapy Research 21: 501-506.

Chatap PB , Deshmukh UB,Telkhede PM (2020) An Invasion of Achatina fulica Bowdich in Chandrapur District (Vidarbha Region), Maharashtra (India). International Research Journal of Science and Engineering: Special Issue A7: 417-421.

Ciomperlik MA, Robinson D, Gibbs IH, Fields A, Stevens T, Taylor BM (2013) Mortality to the giant African snail, Lissachatina fulica (Gastropoda: Achatinidae), and non-target snails using select molluscicides. Florida Entomologist 96: 370-379.

Daihan SA (2008) Measurement of selected enzymatic activities in Solanum nigrum - treated Biomphalaria arabica snails. Journal of Applied Sciences 8:881-885.

Doleželová $\mathrm{P}$, Mácová S, Plhalová L, Pištěková V, Svobodová Z (2011) The acute toxicity of clove oil to fish Danio rerio and Poecilia reticulata. Acta Veterinaria Brno 80: 305-308.

Ellman GL, Courtney KD, Andres VJr, Featherstone RM (1961) A new and rapid colorimetric determination of acetylcholinesterase activity. Biochemical Pharmacology 7:88-95.

Fiske CH, Subbarow Y (1925) Quantitative and qualitative analysis of lipids and lipid components. In: Colowick SP, Kaplan NO (Eds). Methods in Enzymology, Vol. 14, Academic Press Inc, New York.

Gohary EI, Laila RA, Genena MAM (2011) Biochemical effect of three Molluscicide baits against the two land snails, Monacha cantiana and Eobania vermiculata (Gastropoda: Helicidae). International Journal of Agricultural Research 6: 682-690.

Isman M (1999) Pesticides based on plant essential oils. Pestic Outlook 10: 68-72.

Jayashankar M, Sridhar V, Verghese A (2013) Review article: Management of the giant African snail, Achatina fulica (Bowdich) (Stylommatophora: Achatinidae) in India. Pest Management in Horticultural Ecosystems 19: 1-9.

Justin CGL, Leelamathi M, Johnson SBN, Thangaselvabai T (2008) Seasonal incidence and management of the giant African snail, Achatina fulica (Bowdich) (Gastropoda: Achatinidae) on vanilla. Pest Management and Economic Zoology 16: 235-238. 
Kashyap S , Khagta S , Guleria K, Arya V (2019) Plants as Molluscicides: A recent update. International Journal of Botany Studies 4: 50-56.

Khalil AM (2015) Toxicological effects and oxidative stress responses in freshwater snail, Lanistes carinatus, following exposure to chlorpyrifos. Ecotoxicology and Environmental Safety 116:137-142.

King J (1965) Practical Clinical Enzymology. Van Nostrand D Company Inc, London.

Kopecka J, Pempkowiak J (2004) AChE as biomarker of mussels and fish contamination with chemicals in the Gulf of Gdansk Annals of Environmental Protection 6: 99-106.

Kumar P, Jaiswal P, Singh VK, Singh DK (2011) Medicinal, Therapeutic and Pharmacological effects of Syzgium aromaticum (Laung). Pharmacology online (Newsletter) 1: 1044-1055.

Lowe S, Browne M, Boudjrlas S, De Poorter M (2000) 100 of the world's worst invasive alien species: A selection from the global invasive species database. The Invasive Species Specialists Group of the Species Survival Commission of the World Conservation Union, Hollands Printing, Auckland, New Zealand.

Lowry OH, Rosebrough NJ, Farr AL, Randall RJ (1951) Protein measurement with the folin phenol reagent. Journal of Biological Chemistry 193: 265-275.

Mahmoud AH, Darwish NM, Kim YO, Viayaraghavan P, Kwon JT, Na SW, Lee JC, Kim HJ (2020) Fenvalerate induced toxicity in Zebra fish, Danio rerio and analysis of biochemical changes and insights of digestive enzymes as important markers in risk assessment. Journal of King Saud University - Science 32: 15691580.

Ming J, Lin PH, Qizhi Y, Changyi C (2010) Chemical and molecular mechanism of antioxidants: experimental approaches and model systems. Journal of Cellular and Molecular Medicine 14: 840-860.

Moron MS, Depierre JW, Mannervik B (1979) Levels of glutathione, glutathione reductase and glutathione-S-transferase activities in rat lung and liver. Biochimica et Biophysica Acta 582: 67-68.

Naggs F (1997) William Benson and the early study of land snails in British India and Ceylon. Archives of Natural History 24: 37-88.

Nelson S (2012) Injuries caused by the Giant African snail to Papaya. Miscellaneous pests. College of Tropical Agriculture and Human resources, University of Hawaii at Manoa, 1-7. https://www.ctahr.hawaii.edu/oc/freepubs/pdf/MP-6.pdf.
Okhawa H, Ohishi N, Yagi K (1979) Assay for lipid peroxides in animal tissues by thiobarbituric acid reaction. Analytical Biochemistry 95: 351-358.

Palma JM, Sandalio LM, Lorpas FJ, Puertas MCR, McCarthy I, del Rio LA (2002) Plant proteases, protein degradation and oxidative stress: role of peroxisomes. Plant Physiology and Biochemistry 40: 521-530.

Parvate YA, Bhori M, Thayil L (2016) Effect of clove oil on the Albumen gland and reproductive potential of Achatina fulica. International Journal of Advanced Biotechnology and Research 7: $2177-2184$

Parvate YA, Thayil L (2017) Toxic effect of Clove oil on the survival and histology of various tissues of pestiferous land snail Achatina fulica (Bowdich, 1822). Journal of Experimental Biology and Agricultural Sciences 5: 492-505.

Rao IG, Singh DK (2000) Effect of Single and Binary Combinations of Plant derived Molluscicides on Reproduction and Survival of the Snail Achatina fulica. Archives of Environmental Contamination and Toxicology 39: 486-493.

Raut SK, Barker GM (2002) Achatina fulica Bowdich and Other Achatinidae as Pests in Tropical Agriculture. In: Barker GM (Ed). Molluscs as Crop Pest, CABI Publishing, Hamilton, New Zealand.

Raut SK, Ghose KC (1984) Pestiferous Land Snails of India. Zoological Survey of India, Calcutta, Technical Monograph no. 11: 1-151.

Sajeev TV (2011) Public management tools in invasive species management. APFISN workshop on forest health technology and phytosanitary standards, Beijing, China.

Saxena RM, Mahendra, VK (2000) An introduction to giant African snail, Achatina fulica, its destructive ability and an attempt to control by using bait technique. Flora and Fauna 6: 27-28.

Schaller A (2004) A cut above the rest: the regulatory function of plant proteases. Planta 220: 183-197.

Schneider WC (1957) Determination of nucleic acid in tissues by pentose analysis. In: Colowick SP Kaplan NO (Eds). Methods in Enzymology, Vol. 3, Academic Press Inc, New York.

Shalaby S, El-Din MM, Abo-Donia SA, Mettwally M, Attia ZA (2011) Toxicological Affects of Essential Oils from Eucalyptus Eucalyptus globules and Clove Eugenia caryophyllus on Albino Rats. Polish Journal of Environmental Studies 20: 429-434.

Shevale BS, Bedse VL (2009) Evaluation of different poison baits for the management of giant African snail, Achatina fulica 
Bowdich. Pest Management in Horticultural Ecosystems 15: Sciences 16: 203-267.

147-149.

Singh RN, Kumar P , Kumar N, Singh DK (2020) Efficacy of binary combination of Deltamethrin+MGK-264 on levels of biochemical changes in the snail Lymnaea acuminata. International Journal of Pharmacy and Pharmaceutical Sciences 12: 111-116.

Singh RN, Kumar P, Singh VK, Singh DK (2010) Toxic effects of Deltamethrin on the levels of biochemical changes in the snail Lymnaea acuminata. Journal of Pharmacy Research 3: 1739-1742.

Singh SK, Singh A (2010) Metabolic changes in freshwater harmful snail Lymnaea acuminate due to aqueous extract of bark and leaf of Euphorbia pulcherima plant. American-Eurasian Journal of Toxicological Sciences 2: 13-19.

Singh SK, Singh SK, Singh A (2013) Toxicological and biochemical alterations of apigenin extracted from seed of Thevetia peruviana, a medicinal plant. Journal of Biodiversity and Environmental Sciences 3: B1 10-B1 19.

Tao Y, Pan L, Zhang H, Tian S (2013) Assessment of the toxicity of organochlorine pesticide endosulfan in clams Ruditapes philippinarum. Ecotoxicology and Environmental Safety 93: 22-30.

Vanitha K, Karuppuchamy P, Sivasubramanian P (2008) Comparative efficacy of bait traps against giant African snail, Achatina fulica attacking vanilla. Annals of Plant Protection
Verma RS, Mehta A, Srivastava N (2007) In vivo chlorpyrifos induced oxidative stress: attenuation by antioxidant vitamins. Pesticide Biochemistry and Physiology 88: 191-196.

Vitta A, Polseela R, Nateeworanart S, Tattiyapong M (2011) Survey of Angiostrongylus cantonensis in rats and giant African land snails in Phitsanulok Province, Thailand. Asian Pacific Journal of Tropical Medicine 4: 597-599.

Wang W, Mao Q, Yao J, Yang W, Zhang Q, Lu W, Deng Z, Duan L (2018) Discovery of the pyridylphenylureas as novel molluscicides against the invasive snail Biomphalaria straminea, intermediate host of Schistosoma mansoni. Parasites \& Vectors 11: 291-298.

Windle HJP, Kelleher D (1997) Identification and Characterization of a metalloprotease activity from Helicobacter pylori. Infection and Immunity 65: 3132-3137.

Yadav RP, Singh A (2016) Toxicity of Two Common Euphorbiales Effect on Metabolism and Enzyme System of Freshwater Snail Lymnaea acuminata. International Journal of Traditional and Natural Medicines 6: 52-60.

Zitka O, Sylvie S, Jaromir G, Michal M, Vojtech A, Jaromir H, Libuse T, Jarmila K, Eckschlager T, Kizek T (2012) Redox status expressed as GSH: GSSG ratio as a marker for oxidative stress in paediatric tumour patients. Oncology Letters 4:1247-1253. 